\title{
REAKSI PASAR SAHAM TERHADAP PENGUMUMAN PERUBAHAN PERINGKAT OBLIGASI PADA PERUSAHAAN YANG TERDAFTAR DI BURSA EFEK INDONESIA
}

\author{
Meilia Rakhmawati \\ Dyah Fitriani
}

Universitas Ahmad Dahlan

\begin{abstract}
Investor decision in buying or selling stocks very influenced by information accepted. Change of obligation rating announcement represent one of new information publicized to public. This research aim to know how the stock market reaction to change of obligation rating announcement for company listed Indonesia stock exchange. Data used by is data of announcement rating from PT. Pefindo. The population of this research are all companies that announce IDX bond rating in the period 20082009. Result of research show in case of decrease of obligation rating is not found by the existence of negativity reaction which significant of during period test that goes on. while for the case of increase of obligation rating not found by the existence of positive reaction significant of during used test period. Inexistence react the market can because of capital market of Indonesia which not yet enough great at manage information circulating so that interpretation for existing information do not yield the correct invesment decision.
\end{abstract}

Keywords : change of obligation rating announcement, stocks market reaction.

\section{PENDAHULUAN}

Perkembangan pasar modal di Indonesia dalam beberapa tahun ini menjadikan para pelaku bisnis melirik keberadaannya. Di samping karena kebijakan pemerintah, tapi juga karena karakteristik pasar modal yang memang dalam beberapa hal memiliki daya saing tersendiri dibanding dengan jenis-jenis pembiayaan usaha lainnya

Di dalam pasar modal Indonesia ada berbagai macam sekuritas, pemodal diberi kesempatan untuk memilih di antara berbagai sekuritas tersebut. Salah satu sekuritas yang diperdagangkan di pasar modal adalah obligasi.
Obligasi merupakan surat pengakuan utang yang diterbitkan oleh pemerintah maupun perusahaan swasta kepada investor, di mana utang ini akan dibayarkan pada masa yang ditentukan. Atas pinjaman tersebut investor diberi imbalan berupa bunga. Sebagai salah satu instrumen yang dikenal dipasar modal, penerbitan obligasi dari suatu perusahaan merupakan sesuatu yang sangat menguntungkan dibandingkan dengan pinjaman bank, karena pembayaran bunga pada obligasi lebih rendah dan dapat dibayar secara berkala, 6 bulan atau setahun sekali.

Suatu obligasi sebelum ditawarkan kepada masyarakat pemodal, terlebih dahulu diperingkat (rating) oleh lembaga pemeringkat 
(rating agency). Proses pemeringkatan berguna untuk menilai kinerja perusahaan dari berbagai faktor yang secara langsung maupun tidak langsung berhubungan dengan keuangan perusahaan. Informasi perubahan peringkat, baik penurunan maupun kenaikan peringkat akan dijadikan investor sebagai acuan untuk memperkirakan pendapatan dan risiko yang dihadapi. Bila perubahan peringkat yang sekarang lebih tinggi dari peringkat yang lalu, maka hal tersebut mencerminkan kondisi finansial perusahaan yang baik. Investor akan menganggap informasi tersebut sebagai suatu isyarat yang positif, sehingga investor akan membeli saham perusahaan tersebut. Sebaliknya, bila informasi perubahan peringkat yang sekarang lebih rendah dari peringkat yang lalu, maka investor akan berfikir bahwa kondisi perusahaan lebih buruk dari sebelumnya. Investor akan menganggap informasi tersebut sebagai suatu isyarat negatif dan akan segera menjual saham perusahaan tersebut walaupun harga sahamnya turun. Tindakan investor inilah yang akan menyebabkan perubahan harga saham pada perusahaan penerbit obligasi.

\section{REVIEW LITERATUR DAN HIPOTESIS}

\section{Pasar Modal}

Pasar modal adalah pertemuan antara pihak yang memiliki kelebihan dana dengan pihak yang membutuhkan dana dengan memperjualbelikan sekuritas yang umumnya memiliki umur lebih dari satu tahun, seperti saham dan obligasi. Sedangkan tempat terjadinya jual beli sekuritas yaitu bursa efek. Bursa efek merupakan arti dari pasar modal secara fisik. Pasar modal mempunyai peran strategis sebagai salah satu sumber pembiayaan bagi dunia usaha. Dalam perkembangannya, dunia usaha mampu berperan sebagai mobilitas dana dengan mendistribusikan kekayaan melalui mekanisme yang mampu melipatgandakan transaksi jual beli saham.

\section{Saham}

Saham merupakan salah satu tanda bukti kepemilikan atau keikutsertaan dari pihak luar perusahaan (Tandelilin, 2001:18). Dengan memiliki saham suatu perusahaan maka investor akan mempunyai hak terhadap pendapatan dan kekayaan perusahaan setelah dikurangi dengan pembayaran semua kewajiban perusahaan. Saham dalam suatu perdagangan di pasar modal merupakan suatu sekuritas yang sangat populer karena saham dapat memberikan keuntungan dalam jumlah yang besar dalam waktu yang relatif singkat.

\section{Obligasi}

Obligasi pada dasarnya merupakan surat pengakuan utang atas pinjaman yang diterima oleh perusahaan penerbit obligasi dari masyarakat pemodal. Jangka waktu obligasi telah ditetapkan dan disertai dengan pemberian imbalan bunga yang jumlah dan saat pembayarannya telah ditetapkan dalam perjanjian (Sunariyah, 2006). Menurut Darmadji dan Fakhruddin (2006) obligasi adalah surat berharga yang menunjukkan bahwa penerbit obligasi meminjam sejumlah dana kepada masyarakat dan memiliki kewajiban untuk membayar bunga secara berkala, dan kewajiban melunasi pokok utang pada waktu yang telah ditentukan kepada pihak pembeli obligasi tersebut.

Hasil yang bisa didapatkan dari investasi pada obligasi yaitu kupon yang merupakan bunga dari obligasi dan capital gain, yang merupakan selisih harga beli dengan harga jual obligasi. Investor bisa mensyaratkan tingkat hasil (rate of return) yang dikehendaki dengan membandingkan obligasi itu dengan alternatif investasi lain yang sebanding yang tersedia di pasar. Jika hasil yang disyaratkan pasar sama dengan hasil yang dijanjikan obligasi, maka harga obligasi akan sama dengan nilai nominalnya. Jika hasil yang disyaratkan pasar lebih tinggi dari hasil yang dijanjikan obligasi, maka harga 
obligasi akan berada di bawah nilai nominalnya, atau dijual secara discount. Jika hasil yang disyaratkan pasar lebih rendah dari hasil yang dijanjikan obligasi maka harga obligasi akan berada di atas nilai nominalnya, atau dijual secara premium (Fabozzi, 2000).

\section{Peringkat Obligasi}

Pemeringkatan terhadap obligasi yang akan diterbitkan bertujuan untuk menilai kinerja perusahaan. Proses pemeringkatan obligasi dilakukan oleh suatu lembaga pemeringkat (rating agency). Lembaga pemeringkat yang ada di Indonesia adalah PT. PEFINDO (Pemeringkat Efek Indonesia). Pemeringkatan terhadap obligasi dinilai sangat penting karena dapat dimanfaatkan untuk memutuskan apakah obligasi tersebut layak terbit atau tidak serta mengetahui tingkat risikonya. Peringkat (rating) yang diberikan oleh rating agency akan menyatakan apakah obligasi tersebut berada pada peringkat investment grade atau non investment grade. Suatu obligasi yang memperoleh rating non investment grade maka obligasi tersebut disebut dengan istilah junk bond (obligasi sampah).

Tabel 1

Simbol Peringkat PT. PEFINDO

\begin{tabular}{|c|c|}
\hline $\begin{array}{c}\text { Simbol } \\
\text { Peringkat }\end{array}$ & Kategori \\
\hline $\mathrm{AAA}$ & Investment Grade \\
$\mathrm{AA}$ & (layak untuk investasi) \\
$\mathrm{A}$ & \\
$\mathrm{BBB}$ & Non Investment Grade \\
$\mathrm{BB}$ & (tidak layak untuk \\
$\mathrm{B}$ & investasi) \\
$\mathrm{CCC}$ & \\
$\mathrm{D}$ & \\
\hline
\end{tabular}

Tanda (+) atau (-) bisa ditambahkan di belakang rating untuk menegaskan tingkat rating lebih lanjut. Sebagai contoh, suatu perusahaan barangkali mempunyai rating $\mathrm{A}+$, yang berarti rating A tingkat atas.

\section{Reaksi Pasar Terhadap Pengumuman Perubahan Peringkat Obligasi}

Pengumuman perubahan peringkat dapat diartikan positif dan dapat pula diartikan negatif oleh investor. Informasi perubahan peringkat yang diterima oleh investor akan dipertimbangkan menjadi suatu penilaian yang mempengaruhi keputusan investasinya. Investor mengartikan informasi tersebut sebagai hal yang positif, apabila peringkat obligasi tinggi, mencerminkan keadaan finansial perusahaan yang baik, atau bila peringkat obligasi mengalami kenaikan dari peringkat sebelumnya.

Sebaliknya, informasi baru dinilai negatif oleh investor, bila peringkat obligasi mengalami penurunan. $\mathrm{Hal}$ ini membuat investor ragu akan keadaan finansial perusahaan tersebut dan mulai berfikir akan risiko terburuk yang mungkin akan dideritanya. Hal ini membuat investor bereaksi negatif, yaitu dengan menjual saham perusahaan tersebut.

\section{Hipotesis}

Reaksi pasar terhadap pengumuman perubahan peringkat obligasi ditunjukkan dengan adanya abnormal return yang terjadi setelah adanya suatu peristiwa, bila nilai abnormal return lebih kecil dari nol dan signifikan pada tingkat signifikansi, maka pasar bereaksi negatif. Pasar bereaksi positif bila nilai abnormal return yang terjadi menunjukkan lebih besar dari nol, dan signifikan pada tingkat signifikansi. Berdasarkan uraian diatas, hipotesis yang akan diuji dalam penelitian ini adalah :

H1 : Pasar bereaksi negatif terhadap pengumuman penurunan peringkat obligasi. 
H2 : Pasar bereaksi positif terhadap pengumuman kenaikan peringkat obligasi.

\section{METODE PENELITIAN}

Populasi, Sampel, dan Teknik Pengambilan Sampel

Sampel yang digunakan dalam penelitian ini adalah perusahaan yang obligasinya diperingkat oleh PT. Pefindo yang sahamnya go public di Bursa Efek Indonesia (BEI) mulai januari 2008 sampai dengan desember 2009 yang berjumlah 31 perusahaan. Sedangkan metode yang digunakan untuk menentukan sampel adalah dengan metode purposive sampling.

Jenis dan sumber data yang digunakan dalam penelitian ini adalah data sekunder, yaitu :

1. Data tanggal pengumuman peringkat obligasi dari tahun 2008 - 2009 yang diperoleh dari PT Pefindo.

2. Harga pasar saham dan indeks harga saham gabungan dari tahun 2008 - 2009 yang diperoleh dari Bursa Efek Indonesia dan Harian Bisnis Indonesia.

\section{Analisa Data}

Sampel dikelompokkan menjadi dua kelompok, kelompok pertama adalah kelompok sampel perusahaan yang mengalami penurunan peringkat obligasi. Kelompok kedua adalah kelompok sampel perusahaan yang mengalami kenaikan peringkat obligasi.

\section{Perhitungan Return Aktual}

Return aktual setiap perusahaan sampel dihitung mulai 5 hari sebelum ( $t-5$ ) pengumuman perubahan peringkat obligasi dan 5 hari sesudah $(\mathrm{t}+5)$ pengumuman perubahan peringkat obligasi. Return aktual dari setiap kelompok perusahaan sampel dihitung berdasar rumus :

$\mathrm{R}_{\mathrm{it}}=\frac{P_{t}-P_{t-1}}{P_{t-1}}$
Dimana :

$\mathrm{R}_{\mathrm{it}}$ : Return aktual saham i pada periode $\mathrm{t}$

$P_{t}$ : Harga saham saat $t$

$\mathrm{P}_{\mathrm{t}-1}:$ Harga saham saat $\mathrm{t}-1$.

Perhitungan Return Pasar.

Return pasar setiap kelompok perusahaan sampel dihitung sejak 5 hari sebelum (t-5) sampai dengan 5 hari setelah $(t+5)$ tanggal pengumuman peringkat obligasi. Return pasar dihitung dengan rumus :

$\mathrm{R}_{\mathrm{mt}}=\frac{I H S G_{t}-I H S G_{t-1}}{I H S G_{t-1}}$

Dimana :

$\mathrm{R}_{\mathrm{mt}} \quad:$ Return pasar pada periode $\mathrm{t}$

$\mathrm{IHSG}_{\mathrm{t}} \quad$ : Indeks pasar pada periode $\mathrm{t}$

IHSG $_{\mathrm{t}-1} \quad:$ Indeks pasar pada periode $\mathrm{t}-1$

Menentukan Nilai Alpha dan Beta.

Perhitungan expected return dengan model pasar (market model). Model ekspektasi dapat dibentuk menggunakan teknik regresi OLS (Ordinary Least Square).

Keterangan :

$$
\mathrm{R}_{\mathrm{it}}=\alpha_{\mathrm{i}}+\beta_{\mathrm{i}} \cdot \mathrm{R}_{\mathrm{mt}}+\mathrm{e}_{\mathrm{it}}
$$

$\mathrm{R}_{\mathrm{it}} \quad$ : Return aktual saham i pada periode $\mathrm{t}$

$\mathrm{R}_{\mathrm{mt}} \quad$ : Return pasar pada periode $\mathrm{t}$

$\alpha_{\mathrm{i}} \quad$ : Pendapatan konstan saham i

$\beta_{\mathrm{i}} \quad$ : konstanta kepekaan pendapatan saham terhadap indeks

$\mathrm{e}_{\text {it }}$ : kesalahan residu dalam periode $\mathrm{t}$.

Perhitungan Expected Return.

Dari setiap kelompok perusahaan sampel, yaitu kelompok yang mengalami penurunan dan kelompok yang mengalami kenaikan peringkat obligasi, dihitung expected return dengan menggunakan persamaan :

$$
\mathrm{E}\left(\mathrm{R}_{\mathrm{it}}\right)=\alpha_{\mathrm{i}}+\beta_{\mathrm{i}} \cdot \mathrm{R}_{\mathrm{mt}}
$$


Dimana :

$\mathrm{E}\left(\mathrm{R}_{\mathrm{it}}\right)$ : Expected return saham i pada periode $\mathrm{t}$

$\alpha_{i} \quad$ : pendapatan konstan saham i

$\beta_{\mathrm{i}} \quad$ : konstanta kepekaan pendapatan saham terhadap indeks.

$\mathrm{R}_{\mathrm{mt}} \quad$ : return pasar pada periode $\mathrm{t}$.

Perhitungan Abnormal Return.

Abnormal return merupakan selisih antara return aktual dengan return ekspektasi, setelah diketahui besarnya expected return maka dapat diketahui nilai abnormal return selama periode uji dari setiap kelompok perusahaan sampel yang diteliti. Abnormal return dihitung dengan persamaan :

Dimana :

$$
A R_{i t}=R_{i t}-E\left(R_{i t}\right)
$$

$\mathrm{AR}_{\text {it }} \quad$ : abnormal return saham i pada periode $\mathrm{t}$ $\mathrm{R}_{\mathrm{it}} \quad$ : return aktual saham i pada periode $\mathrm{t}$ $E\left(R_{i t}\right)$ : expected return saham i pada periode $t$

\section{Perhitungan Cumulative Abnormal Return.}

Nilai Cumulatif abnormal return diperoleh dengan persamaan :

$$
\mathrm{CAR}_{\mathrm{t}}=\sum_{t=1}^{n} \text { ARit }
$$

Keterangan :
$\mathrm{CAR}_{t}$ : Cumulative abnormal return pada periode $t$

$\mathrm{AR}_{\text {it }}:$ Abnormal return pada periode $\mathrm{t}$

n : jumlah sampel

Perhitungan Average Cumulative Abnormal Return.

Average Cumulative abnormal return dihitung dengan persamaan :

$$
\text { ACARt }=\frac{1}{n} \sum_{t=1}^{n} \text { CARt }
$$

Keterangan:

$$
\begin{aligned}
& \mathrm{ACAR}_{\mathrm{t}} \text { : average cumulative abnormal } \\
& \text { return pada periode } \mathrm{t} \\
& \mathrm{CAR}_{\mathrm{it}} \text { : cumulative abnormal return } \\
& \text { pada periode } \mathrm{t} \\
& \text { n : jumlah sampel. }
\end{aligned}
$$
difference pada output SPSS.

\section{Pengujian Hipotesis}

Pengujian hipotesis, yaitu dengan menggunakan uji t satu sampel terhadap abnormal return dilakukan pada kelompok pertama dan kedua.

1. Rumusan hipotesis pertama.

Ho1 : pasar saham tidak bereaksi terhadap pengumuman penurunan peringkat obligasi.

Ha1 : Pasar saham beraksi negatif terhadap pengumuman penurunan peringkat obligasi.

2. Rumusan hipotesis kedua.

Ho2 : Pasar saham tidak bereaksi terhadap pengumuman kenaikan peringkat obligasi.

$\mathrm{Ha} 2$ : Pasar saham bereaksi positif terhadap pengumuman kenaikan peringkat obligasi.

3. Menentukan besarnya Level of Significance (LOS) $\alpha=5 \%$

4. kriteria pengujian sebagai berikut: jika nilai sig $(2$-tailed $)<\alpha$, maka tolak Ho. Jika nilai sig $(2$-tailed $)>\alpha$, maka tolak $\mathrm{Ha}$. 
HASIL PENELITIAN DAN PEMBAHASAN

\section{Hasil Penelitian}

Tabel 1

\begin{tabular}{|c|r|r|}
\hline Keterangan & \multicolumn{1}{|c|}{ Uji t } & \multicolumn{1}{|c|}{ Sign } \\
\hline AR-5 & -2.571 & .062 \\
AR-4 & 1.504 & .207 \\
AR-3 & -.055 & .959 \\
AR-2 & .044 & .967 \\
AR-1 & -.892 & .423 \\
AR0 & .727 & .507 \\
AR1 & -.648 & .552 \\
AR2 & -1.791 & .148 \\
AR3 & -.113 & .915 \\
AR4 & .950 & .396 \\
AR5 & -1.421 & .228 \\
\hline
\end{tabular}

Pengujian untuk nilai abnormal return dalam periode uji ini dilakukan dengan uji t satu sampel, selama 5 hari sebelum pengumuman penurunan peringkat obligasi (t-5) sampai dengan 5 hari sesudah pengumuman penurunan peringkat obligasi $(t+5)$. Jumlah data dalam kelompok perusahaan yang mengalami penurunan peringkat obligasi adalah sebanyak 5 sampel perusahaan. Berdasarkan hasil analisis data dengan bantuan program SPSS diperoleh hasil bahwa average cumulative abnormal return saham perusahaan sampel selama periode uji tidak ada yang signifikansinya lebih kecil dari 0 , dan diperoleh thitung yang bernilai positif namun tidak signifikan pada tingkat signifikansi $(\alpha) 5 \%$. Dalam uji hipotesis pertama ini hasilnya adalah terima Ho. Hal ini disebabkan karena nilai Sig. (2-tailed $)>0,05$. Artinya pasar tidaklah bereaksi negatif terhadap pengumuman penurunan peringkat obligasi yang dikeluarkan oleh PT. Pefindo. Hasil uji t satu sampel perusahaan yang mengalami penurunan peringkat obligasi dapat dilihat pada tabel 2 .
Tabel 2

\begin{tabular}{|c|r|c|}
\hline Keterangan & Uji t & Sign \\
\hline AR-5 & -.931 & .369 \\
AR-4 & -1.878 & .083 \\
AR-3 & -.508 & .620 \\
AR-2 & -1.439 & .174 \\
AR-1 & .675 & .512 \\
AR0 & 1.203 & .250 \\
AR1 & 2.508 & .026 \\
AR2 & -.174 & .864 \\
AR3 & -1.110 & .287 \\
AR4 & .574 & .576 \\
AR5 & -.710 & .490 \\
\hline
\end{tabular}

Jumlah data dalam kelompok perusahaan yang mengalami kenaikan peringkat obligasi adalah sebanyak 14 sampel perusahaan. Dari sampel perusahaan yang mengalami kenaikan peringkat obligasi dilakukan uji t satu sampel terhadap nilai abnormal return selama periode uji. Berdasarkan hasil analisis data dengan bantuan program SPSS diperoleh hasil bahwa pasar tidak bereaksi positif terhadap pengumuman kenaikan peringkat obligasi. Dimana signifikansi t hitung selama periode uji sebagian besar menunjukkan angka lebih besar dari tingkat signifikansi $(\alpha)$ $5 \%$. Sehingga hipotesis yang menyatakan pasar bereaksi positif terhadap pengumuman kenaikan peringkat obligasi tidak diterima. Dapat dikatakan bahwa tidak ada reaksi pasar dari peristiwa kenaikan peringkat obligasi. Dengan hal ini berarti terima Ho, karena nilai Sig.(2-tailed $)>0,05$. Hasil uji t satu sampel perusahaan yang mengalami kenaikan peringkat obligasi dapat dilihat pada tabel 2.

\section{Pembahasan}

Hasil Pengujian Hipotesis Pertama yang menunjukkan bahwa pasar tidaklah bereaksi negatif terhadap pengumuman penurunan peringkat obligasi ditunjukkan dengan nilai ACAR. Selama periode uji lebih banyak nilai ACAR yang negatif namun tidak signifikan, dari nilai t hitung yang negatif tersebut berarti pasar bereaksi negatif 
terhadap penurunan peringkat obligasi, namun reaksi pasarnya tidaklah signifikan. Hasil ACAR yang tidak signifikan tersebut mendukung hasil penelitian ini, yaitu pasar tidak bereaksi negatif terhadap pengumuman penurunan peringkat.

Sedangkan pengujian hipotesis kedua yang menyatakan pasar bereaksi positif terhadap kenaikan peringkat obligasi tidak bisa diterima. Hal tersebut dapat dilihat pada nilai ACAR, selama periode pengamatan terdapat nilai ACAR yang negatif namun tidak signifikan. Dari nilai t hitung yang negatif tersebut berarti pasar bereaksi negatif terhadap kenaikan peringkat obligasi namun reaksi pasarnya tidaklah signifikan. Tetapi dalam periode pengamatan ini terdapat satu nilai ACAR yang positif signifikan pada hari setelah pengumuman kenaikan obligasi.

\section{KESIMPULAN DAN SARAN}

Tidak adanya reaksi pasar terhadap peristiwa perubahan peringkat obligasi, baik itu penurunan maupun kenaikan peringkat obligasi ini dapat disebabkan karena investor menganggap informasi perubahan peringkat obligasi hanya sebagai informasi pelengkap saja, bukan merupakan suatu kejadian yang dapat mempengaruhi keputusan investasi para investor. Dapat juga disebabkan karena pengumuman peringkat obligasi belum tentu merefleksikan baik buruknya kinerja perusahaan dimasa yang akan datang. Namun hal tersebut masih harus dibuktikan lewat penelitian-penelitian yang menguji lebih dalam mengenai bentuk efisiensi pasar modal di Indonesia.

Bagi lembaga pemeringkat, hendaknya mengkaji lebih dalam mengenai pemeringkatan yang telah dipublikasikan ke masyarakat, serta melakukan review secara berkala terhadap kemampuan finansial perusahaan-perusahaan yang diperingkat. Bagi Investor, diharapkan dapat mengkaji ulang informasi-informasi yang didapatkan, sebelum mengambil keputusan investasinya. Bagi Perusahaan, sebaiknya mengevaluasi faktor-faktor lain selain perubahan peringkat obligasi, seperti stock split, merger, akuisisi, dll. Hal ini karena pengumuman peringkat obligasi secara keseluruhan belum mampu mempengaruhi perubahan harga saham yang berarti. Bagi peneliti selanjutnya, diharapkan tidak hanya meneliti pengaruh peringkat obligasi saja, dapat ditambahkan faktor-faktor lain seperti kebijakan suku bunga, faktor demand dan supply pasar, dan faktor-faktor lainnya guna memberikan generalisasi hasil penelitian.

\section{DAFTAR PUSTAKA}

Darmadji, Tjiptono dan Fakhruddin. 2001. Pasar Modal di Indonesia Pendekatan Tanya Jawab. Edisi Pertama. Jakarta: Salemba Empat.

Fabozzi, Frank J. 2000. Manajemen Investasi. Edisi 1. Buku 2. Jakarta: Salemba Empat.

, Frank J. 2000. Bond Markets, Analysis dan Strategies. Fifth Edition. New Jersey: Prentice Hall.

Hanafi, Mamduh M. 2004. Manajemen Keuangan. Cetakan pertama. Yogyakarta: BPFE.

Jogiyanto, H. M. 2005. Pasar Efisien Secara Keputusan. Yogyakarta: BPFE . 2003. Teori Portofolio dan Analisis Investasi. Yogyakarta: BPFE-UGM

Nuroniah. 2008. Perbedaan Abnormal Return dan Volume Perdagangan Saham di Seputar Pengumuman Kenaikan Bond Rating Pada Perusahaan yang Listing di Bursa Efek Jakarta. Skripsi. Yogyakarta: Universitas Ahmad Dahlan.

Rahardjo, Sapto. 2003. Panduan Investasi Obligasi. Jakarta: PT. Gramedia Pustaka Utama. 
Rahayu, Aprilia Dyah. 2007. Pengaruh Pengumuman Perubahan Bond Rating Terhadap Abnormal Return Perusahaan di Bursa Efek Jakarta. Skripsi. Yogyakarta: Universitas Ahmad Dahlan.

Ratih, Sulistiastuti Dyah. 2006, Saham dan Obligasi. Edisi Pertama. Cetakan Kedua. Yogyakarta: UAJY.

Samsul, Mohamad. 2006. Pasar Modal \& Manajemen Portofolio. Jakarta: Erlangga.
Setiawan, Edi Budiono dan Shanti. 2009. "Reaksi Pasar Saham Terhadap Pengumuman Perubahan Peringkat Obligasi Perusahaan yang Terdaftar Di Bursa efek Indonesia". Modus, Vol 21, hal 73-86.

Sunariyah. 2006. Pengantar Pengetahuan Pasar Modal. Edisi Keempat. Yogyakarta: UPP AMP YKPN.

Tandelilin, Eduardus. 2001. Analisis Investasi dan Manajemen Portofolio. Edisi pertama. Yogyakarta: BPFE.

http://www.pefindo.com 